\title{
ARNOLD WYCOMBE GOMME
}

Through the death of Professor A. W. Gomme, on January i 7 th last, in his seventythird year, the Society has lost its President; the world of scholarship has lost a scholar of distinction and originality, and very many of those connected with Classical studies, both in this country and in many others, have lost a delightful friend. Important though his work was, it is the man himself that all those who knew him would wish to be first commemorated. Few professional scholars have been less obviously the professional scholar; not many Hellenists have been so completely and naturally Hellenic in mind and outlook. $\mathrm{He}$ had an unending willingness to be interested in almost any human activity-not indeed confusing the great with the small, but taking each on its merits; nor was he content to be only the critical or amused spectator, but he was always willing to be active, whether by serving on national or international committees of learned organisations, or by starting a film society or other such enterprise in his own university, or by taking up some public cause in Long Crendon, the village that was always his home, particularly if he felt that injustice or stupidity were afoot. 'Professor X,' he once observed, 'tells me that he enjoys Bridge, as a relaxation from his work. I don't understand that attitude at all; to me, Bridge is simply another thing that one can do.' His alert and critical attitude to nearly everything, which he could express pungently, often indulging his taste for paradox, could be daunting to a casual acquaintance: one could mistake for conscious superiority what was in truth a fundamental simplicity and humanity strengthened by a keen intelligence, and touched, very often, by an elaborate and charming sense of fun. He had a genius for friendship; and it was well said of him, by a Glasgow colleague, that 'he had an enthu-

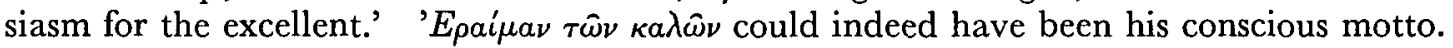

His father, Sir Lawrence Gomme, Clerk to the London County Council, was an authority on the history and antiquities of London, and Lady Alice Gomme, his mother, was a well-known student of English folk-lore. Arnold Gomme was educated at the Merchant Taylors' School and Trinity College, Cambridge; then, after a year at the British School, and a year as Assistant Lecturer at the University of Liverpool, he went to the University of Glasgow, where the rest of his professional life was spent, interrupted by the First World War, when he served in France and in Greece, and by the Second, during which he spent some three years in the Treasury. In Glasgow he was successively Lecturer in Greek, Lecturer in Greek and Greek History, Reader in Greek History, and Professor of Greek. The designation 'Lecturer in Greek and Greek History' was no mere administrative formula; his interest in Greek literature-and in Greek art also-was as lively and as critical as his interest in Greek history, as is shown particularly by his Sather Lectures on the Greek Attitude to History and Art, and by his work on Menander. Especially on Homer, Herodotus and the dramatists he had illuminating things to say, while one of the impressive qualities of his Commentary on Thucydides is the understanding that it shows of Thucydides' mind and style.

His first publication (which he did not choose to list in Who's Who) was a pamphlet (I922) criticising in devastating fashion the Greek section of $\mathrm{H}$. G. Wells' History of the World. It was characteristic: Gomme was the most tolerant of men, but he disliked error and hated the superficial. Where other scholars would ignore, he had to attack and expose. After his well-known monograph on The Population of Athens in the Fifth and Fourth Centuries, there followed, in 1935, his most stimulating and attractive History of Greece, a short work which is not as well known as it deserves: it forms part only of vol. I of a seven-volume work, European Civilisation, edited by Edward Eyre. Gomme wrote also-though with VOL. LXXIX 
some reluctance-the section on the Roman Republic in vol. I I of the same work. His Essays on Greek Subjects appeared next, and then, in 1945, the first volume of his truly notable Commentary on Thucydides. The appearance of the next two volumes was delayed by a personal disaster, which he confronted with characteristic resilience and courage: a suitcase containing all his notes was stolen from a train and never recovered. At the time of his death he had completed his commentary on the remaining part of Book $\mathrm{V}$ and on part of Book VI, and it is good to know that this final volume is now in the hands of Professor Andrewes and Professor Dover. A book on Menander was ready for the press when the discovery of the Dyscolos made its postponement inevitable; it is much to be hoped that this work too will be completed and published.

Gomme was Sather Professor in the University of California in 1952. In 1947 he was elected Fellow of the British Academy, and was for several years the chairman of the Ancient History section. It is fitting here to make special and grateful reference to the many services that he rendered to the Hellenic Society: as member of the Council for several periods, as President, and as an outstanding editor of the Fournal from I95 I to 1958. Greece was indeed his great love; not many Greek scholars have been fortified by a wider knowledge of the country and a more warm-hearted and shrewd understanding of its people. He liked to tell a story of his last visit. He was in Samos, and hired a car to cross the island. 'Naturally, the driver and I talked politics, especially about Cyprus. At the end of the day the driver reproached me, as an Englishman, for taking too narrowly a pro-Greek view of the situation.'

Right to the end he kept his young appearance and his youthful zest for life. His death was untimely, and prevented his giving much that he still had to give; but he was spared what he would have found intolerable, the inactivity of an old age.

H. D. F. K. 